\title{
ETHICS (Effective Technical and Human Implementation of Computer Based Systems): A human oriented information system development
}

\author{
Syawal Gultom ${ }^{1}$, Abil Mansyur $^{2}$, Sriadhi $^{3}$ and Mangaratua M. Simanjorang ${ }^{4}$ \\ \{mangaratuasimanjorang@gmail.com ${ }^{3}$ \} \\ Mathematics dan Natural Science Faculty, Universitas Negeri Medan, Jl. Willem Iskandar Pasar V, \\ Medan, Indonesia ${ }^{1}$ Engineering Faculty, Universitas Negeri Medan, Jl. Willem Iskandar Pasar V, \\ Medan, Indonesia ${ }^{2,3,4}$
}

\begin{abstract}
The policy about teacher professionalism has been applied for last decade in Indonesia. However, science and technology development, changes in society, innovation in teaching and learning theory, and all other changes demand a sustainable teacher empowerment system. Considering this demand, it is necessary for UniversitasNegeri Medan, as an educational institution and also teacher training university, to develop a policy that support the empowerment system of professional teacher. In previous funding term such a system had been developed and one of components of this system is informational system. This article describes an aspect of this informational system development process, which is the development method used to build the informational system. There are many informational system developmental methods available. The question is which one is more suitable for the purpose of empowering teacher sustainably. Considering that the function of the informational system is to connect UniversitasNegeri Medan with the stakeholders including teachers, than the system needs to put importance to the human aspect. Hence the model described in this article is called ETHICS (Effective Technical and Human Implementation of Computer Based Systems). One thatbalances the human and technical aspects in developing the informational system..
\end{abstract}

Keywords: Informational System, ETHICS, Professionalism, Professional Teacher, Teacher Empowerment.

\section{Introduction}

Teacher professionalism is one of the policies that has been implemented since the past decade in Indonesia. The Act of the Republic of Indonesia number 14 year 2005 outlines a number of conditions that must be met by professional teachers including academic qualifications and a number of competencies that teachers must possess. This Act also guarantees the right of teachers to get the opportunity to improve their competence and academic qualifications through training and professional development in their fields. The question are how to manifest this guarantee; what policies need to be developed to support teacher professionalism; What efforts need to be made to improve the competence and qualifications of professional teachers? 
As one of teacher training institutions in Medan Universitas Negeri Medan needs to think about the answers to these questions. Universitas Negeri Medan needs to develop policies that support current legislation for the sake of professional teacher empowerment through teachers self-development. This professional teacher empowerment in the end is expected to improve the quality of education and educational personnel in Indonesia. In this case the policy developed must be based on the principle of professionalism as described in the Act of the Republic of Indonesia number 14 year 2005 article 7 paragraph 2, that the self-development carried out should be democratic, just, non-discriminatory and sustainable by upholding human rights, values religious, cultural values, national pluralism, and professional code of ethics.

As a manifestation of Universitas Negeri Medan's concern to the quality of professional teachers in North Sumatra region an integrated service center system for empowering teachers in North Sumatra has been developed previously in a different research. One variable in this integrated service system is the information system of the integrated service system itself. For that, as a continuation of previous research, this research is intended to develop an information system of integrated service systems developed in the previous year.

However, after the development of the model, a question then arises, "what information system is appropriate with the integrated service center system of professional teacher empowerment that has been developed before?". Such information system is expected to contribute to the efforts of improving the quality of national education services through the empowerment of professional teachers.

Information systems acts as a means to integrate the entire system and also to connect UniversitasNegeri Medan as a service provider with service users (stakeholders). Thus, the information system also acts as a means of dissemination that disseminates important information to anyone who needs it.

\section{Information System}

As previously explained, the information system is one of the integrated service system variables, which functionis to integrate the whole system and also to connect UniversitasNegeri Medan as a service provider with service users (stakeholders). As a means of connecting the information systems should provide necessary information for stakeholders. Besides that this information system must also provide alternative communication channels between UniversitasNegeri Medan and stakeholders.

A system is an integrated and organized unit that is formed from a number of different components and has the same purpose (Ossenbrugen, 1994). There are a lot of notes available for analysts who want to simplify the system. System theory generally tries to understand the nature of a broad and complex system, the same is true in information systems. However, system theory proposes that any model adopted by an analyst needs to consider things beyond the limits set by the adopted model and try to view the system as a whole. Information systems generally have human and computer elements and these two elements are interrelated. Technical elements (computers) are clear and predictable, while human aspects are often open and uncertain. Human aspects tend to be more complex than technical aspects in an information system, because technical aspects tend to be predictable. Many information system methodologies only emphasize technological aspects. This can lead to solutions that do not work effectively, because often methodologies underestimate the importance and 
complexity of human aspects (Avison \& Fitzgerald, 1996). Therefore in this study the research team did not want to be trapped in the rigidity of a particular information system model, but rather try to develop a system that balances human and technical aspects.

Trying to define a system development in this case is not easy because there is no strict agreement regarding this definition in the development of information systems (Huisman \& Iivari, 2002; Avison and Fitzgerald, 1995; Wynekoop and Russo, 1997; Iivari et al., 1999) . Even in the early development of computer-based information systems there was no known explicit development methodology (Coady \& Pooley, 2007; Broady, Walters \& Hartley, 1994). Furthermore Coady and Pooley suggested that any method adopted by an analyst needs to consider things beyond the limits set by the method and try to look at the system as a whole. This is necessary to balance the human element and technical elements in an information system.

\section{Ethics}

ETHICS is an abbreviation of Effective Technical and Human Implementation of Computer-based System. Mumford (1985) defined ETHICS as an approach in designing an information system which is structured and covering organization, administration and working life quality factor, it is also a participatory problem solving method. As the name implies ETHICS is designed to promote ethical and human values. These values are considered by engaging and accommodating the human in the information system. These engagement and accommodation may be seen from stakeholderparticipation(Leitch \& Warren, 2010) in the development process. Participation may be defined as the involvement of stakeholders, who will be affected by the new system, in the decision-making process regarding system design and operation. Furthermore Mumford (2003) described that this participation may be viewed from the structure, content and process aspects.

The structure aspect is related to the mechanism in which the participation occurs, which are through consultation, representation and consensus. In ETHICS approach all stakeholder are encouraged to discuss and to contribute in the designing process. This is how the consultation mechanism happens. This approach also suggests that the representations of the stakeholders are involved in the process. While in the process the development team need to have a consensus with stakeholders regarding the ideas and solutions that are necessary to the system development. The content aspect is related to decision making regarding the development of new information system. This content may explain stakeholders right and level of authority in the new system. The procedure aspect is related to giving user enough knowledge about the new information system that are being developed.

\section{Socio-Technical Approach}

ETHICS uses socio-technical approach in its implementation, which means that in the development process it considers the technical and social aspects. Long (2013) explained that socio-technical is a movement that designs a system in an organization by acknowledging human participation and human's interaction with technology. In other words socio-technical approach is an approach that acknowledges the interaction between human and technology which will result in technically efficient information system and provide satisfaction for the 
users (Mumford, 1985).This satisfaction may come from the correspondence between employee's expectations and assigned tasks. When there is conformity between the expectation and given task then there will be satisfaction. In ETHICS the satisfaction may be measured by using Parson and Shils (1951) framework. This framework based on five dimensions of conformity: knowledge, psychology, efficiency, assignment and structure, and ethics.

Knowledge conformity is satisfied when the employee has enough knowledge to do the work and there is opportunity to improve the knowledge for better competence for doing the work. Psychology conformity is satisfied when the work is compatible with employee's status, improvement and working interest. This dimension may be influenced by employee's age, background, education or social strata. The efficiency dimension related to three components: negotiation between the work and the reward, strictness in workcontrol, and supervision system. Shortly satisfaction may be achieved when there are conformity between workload and the reward, conformity between control strictness and employee's expectation, and conformity between supervision facility provided and the needs. The fourth dimension is measuring the conformity between work demand and the satisfaction from the work. It may related to necessary skills, targets, follow up mechanism, the importance of a task, autonomy and control level possessed by the employee.

\section{Conclusions}

Information system is designed to be used by user, hence it is necessary to consider human aspect in developing the information system. The balance between technical aspect and human aspect may help in developing a more suitable information system. ETHICS includes this consideration in its developmental approach. The socio-technical foundation used in ETHICS shows how it emphasizes the balance of technical and human aspects. Conformity dimension framework used in ETHICS may provide a broad comprehension of the stakeholders' satisfaction which further may be seen as an evidence of its concern on the balance of human and technical aspects.

\section{References}

[1] Avison, D.E., and Fitzgerald, G.: Information Systems Development: Methodologies, Techniques and Tools, McGraw-Hill Publishing Company. Berkshire, England. (1995)

[2] Avison, D. \& Fitzgerald, G.: Information Systems Development, Methodologies, Techniques and Tools, Blackwell Scientific Publications. London (1996)

[3] Broady, J., Walters, S. and Hartley, R.: A Review of Information Systems Development Methodologies (ISDMS). Library Management 15(6), 5-19. (1994)

[4] Coady, J. and Pooley, R.: A Revised Perspective on Documentation Practices in the Modern Organisation. In Magyar, G., Knapp, G., Wojtkowski, W., Wojtkowski, W. G. and Zupančič, J. Advances in Information Systems Development: New Methods and Practice for the Networked Society, Volume 1. Proceedings of the 15th International Conference on Information Systems Development-New Methods and Practice for the Networked Society (ISD 2006), held in Budapest, Hungary, August 31-September 2, 2006. Springer.New York (2007)

[5] Huisman, M. \&Iivari, J.: The organisational deployment of systems development methodologies. 11 th International Conference on Information Systems Development: Methods and Tools, Theory and Practice, Riga, Latvia, September 12-14, 2002. Springer Science + Business Media. New York (2002) 
[6] Iivari, J., Hirscheim, R., and Klein, H.K.: Beyond Methodologies: Keeping up with Information Systems Development Approaches through Dynamic Classification, in: Proceedings ofthe 32ndHawain International Conference on Systems Sciences, pp.1-1 O. (1999)

[7] Leitch \& Warren.: ETHICS: the past, present and future of socio technical systems design. Paper presented at the IFIP advances in information and communication technology (2010)

[8] Long, S.: Socioanalytic methods: discovering the hidden in organizations and social system, Karnac Books. London (2013)

[9] Mumford, E.: Designing human system for new technology: the ETHICS method, Manchester Business school. Manchester. (1985)

[10] Mumford, E.: Redesigning Human Systems, IGI Global. Hershey (2003)

[11] Ossenbrugen, P.J.: Fundamental Principles of Systems Analysis and Decision Making, 1-3, Wiley \& Sons. New York. (1994)

[12] Parson, T. and Shils, E.A.: Values, motives and systems of action. Toward a general theory of action, 33(1951), 247-275. (1951)

[13] Stapleton, L.: ISD as folding together humans \& IT: Towards a revised theory of Information Technology development \& deployment in complex social contexts. In Kirikova, M., Grundspenkis, J., Wojtkowski, W., Wojtkowski, W. G., Wrycza, S., and Zupancic, J. 2002. Information Systems Development: Advances in Methodologies, Components, and Management, Springer. New York. (2002)

[14] Wynekoop, J.L., and Russo, N.L.: Studying system development methodologies: an examination of research methods, Information Systems. Journal, Vol. 7, pp. 47-65. (1997) 